\title{
GREV FRIJS OG BISMARCK I 1869 \\ AF
}

\author{
AAGE FRIIS \\ DR. PHIL., PROFESSOR VED UNIVERSITETET, KøBENHAVN \\ *
}

T Foraaret i 869 saa Grev C. E. Frijs meget mistrøstigt paa Resultaterne af sin hans Ønske, at han ikke kunde træde tilbage. De personlige Forhold indenfor hans Regering var ikke harmoniske; flere af hans Kolleger var syge eller politisk opslidte. $\mathrm{Da}$ han dannede Ministerium i November $\mathrm{r} 86_{5}$, havde hans Forudsætning været, at han kunde samle et stabilt Flertal, ikke blot til Gennemførelse af den nye Forfatning, der kom i Juli 1866, men ogsaa til fortsat politisk Arbejde, ved Mægling mellem modstaaende Anskuelser. Dette syntes ikke at lykkes; Modsætningerne blev stadig større, og Venstreoppositionens Fremstød alvorlige. Det pinte ham, at Traktaten med de nordamerikanske Fristater om Salget af de dansk-vestindiske Øer ikke blev ratificeret af Senatet i Washington, men først og fremmest var det ham en dyb Skuffelse, at der intet havde kunnet udrettes i det nordslesvigske Spørgsmaal, selv efter at dette ved Indføjelsen af Forbeholdet i Pragfredens Art.V var indtraadt i en ny, og som man i første Øjeblik havde maattet haabe, mere lykkelig Fase. Den almindelige storpolitiske europæiske Situation forekom ham højst uhyggelig; han ventede naar som helst Udbrud af en stor Krig mellem Preussen og Frankrig, og det var uberegnelig, om ikke andre med eller mod deres Vilje inddroges deri. Just derfor beklagede han dybt den stadig skærpede indrepolitiske Strid i Danmark; i Marts I869 mente han, at enhver, der havde mindste Smule Bonsens, maatte indse, ,at uden indbyrdes Enighed vilde vi ikke kunne overleve den nuværende Phase i

Ovenstaaende er et Brudstykke af „Den danske Regering og Nordslesvigs Genforening med Danmark", hvis afsluttende Bind tilegnes H. P. HANssen som den Enkeltmand, hvis personlige Indsats betød mest for Nordslesvigs Bevarelse for Danmark i den Periode efter Art. V's Ophævelse, da Arbejdet for Slesvigs Deling gled ud af den danske Regerings Hænder og alene kunde varetages af Nordslesvigs Danske. 
Europas Udvikling"; det var overhovedet et stort Spørgsmaal, om vi ikke trods al Endrægtighed og Forsigtighed vilde blive knuste under den forestaaende almindelige store Kraftprøve, men kom det til at skorte paa de nævnte Egenskaber, vilde vi være redningsløst fortabte ${ }^{1}$. Det huede ham ikke, at der i de tyske Blade fremkom Antydninger om, hvor uheldig den demokratiske Bevægelse $i$ Danmark var; han mistænkte Stormagterne, ganske særlig Preussen, for at have onde Hensigter mod Smaastaterne, og den Maade, hvorpaa siden I866 Forhandlingerne om Nordslesvig var forløbet, fyldte ham med bange Anelser.

Vel havde Bismarck i Maj 1867 taget Initiativ til Forhandlinger med Danmark om Udførelse af Art. V, men i Marts I 868 var de direkte Forhandlinger ophørt, da Preussen havde stillet helt uantagelige Betingelser for Afstaaelsen af en minimal Del af det overvejende danske Nordslesvig. Straks efter var der, atter paa Initiativ af Bismarck, forsøgt at naa et Resultat ved Zar Alexander II som Mellemmand, men denne Vej havde vist sig ufarbar, og Erfaringerne under de hemmelige og vanskelige Forhandlinger for med russisk $\mathrm{Hjælp}$ at opnaa et Resultat havde paa ny lært Danmark, hvor ringe virkelig Støtte det kunde vente af en venligsindet Stormagt; Zaren og hans ledende Minister, Fyrst Gortchakow, var nøje knyttet til Preussen og var øjensynlig parat til at ofre danske Interesser, naar det blot kunde lykkes at bringe et ubehageligt Spørgsmaal ud af Verden. Grev Frijs og Direktøren i Udenrigsministeriet, P. Vedel, hans højre Haand i alle de vigtige udenrigske Forhandlinger, frygtede, at Bismarck, naar han, tilsyneladende af Interesse for en Løsning af det nordslesvigske Spørgsmaal, havde draget Zaren ind i Forhandlingerne, hayde en Bagtanke, nemlig, at Rusland vilde øve et Tryk paa den danske Regering, saaledes at denne maatte lade sig nøje med en ganske utilfredsstillende Grænseændring eller, hvad der var endnu farligere, blev tvunget til som Vederlag for en Stump af Nordslesvig at indgaa politisk eller militærpolitisk Forbindelse med Preussen.

Samtidig med, at disse Forsøg paa at faa Art. V udført var strandet, havde man i Maanederne fra Oktober I 868 til hen paa Foraaret i 869 gjort uhyggelige Erfaringer om Bismarcks Stilling til Optantsporgsmaalet. Dette var efter Krigen I866 og Slesvigs Indlemmelse i Preussen bleven mere og mere ubehageligt; de preussiske militære og civile Myndigheders Optræden mod de værnepligtige, dansksindede Nordslesvigere havde affødt Forholdsregler, der ramte den danske Befolkning haardt, vakte voldsom Forbitrelse i Danmark og, nu for første Gang som stadig siden en Menneskealder igennem, en for Preussen ubehagelig Opmærksomhed i den europæiske Presse. Allerede under denne første Fase af Op-

1 Det nordslesvigske Spørgsmaal 1864-1879 (citeres i det fig.: Akter) II, S. 224 f. 
tantspørgsmaalet var fremtraadt en dybtgaaende Modsætning mellem paa den ene Side Lokalmyndighederne i Slesvig, der ønskede den haardest mulige Behandling af Optanterne, og paa den anden Side Centralregeringen i Berlin. Denne sidste anlagde udenrigspolitiske Synspunkter og paavirkedes i dette Tilfælde navnlig af Hensynet til det Indtryk, som en haardhændet Optantpolitik kunde gøre i St. Petersborg, medens Spørgsmaalet om en Grænseregulering endnu var uafgjort. Resultatet af de meget ubehagelige Forhandlinger om Optanternes Stilling blev i denne Omgang til syvende og sidst relativt tilfredsstillende for Danmark, men den danske Regering havde faaet Indtryk af, at Bismarcks Fortolkning af Wienerfredens Art. XIX stred direkte imod, hvad man fra dansk Side ansaa for soleklar Ret. Paa et givet Tidspunkt talte Grev Frijs og Vedel om, at man eventuelt maatte appellere til den europæiske Offentlighed, men alene denne Antydning fremkaldte en saa voldsom Reaktion fra Bismarcks Side, at den danske Gesandt i Berlin, Quaade, i dybeste Fortrolighed kunde sige til sin russiske Kollega, Baron Oubril, at man paa dette Tidspunkt kun havde været "to Fingersbredder fra en ny Krig "1. Grev Frijs havde faaet den Opfattelse, at Bismarck, „naar den alvorlige Del af Festen begyndte“ ved Udbrudet af en europæisk Krig, endnu mindre end før vilde betænke sig paa noget som helst Retsbrud lige overfor Danmark ${ }^{2}$. Man kunde snarest befrygte et Strejftog mod København; Preusserne vilde vel ikke sætte sig fast der, men, naar de ikke kunde vente at beholde København, mente Grev Frijs, at de vilde handle med endnu større Hensynsløshed end de i 1866 gjorde overfor Frankfurt a/Main. "Det er et lysteligt Fremtidsbillede."

I sine fortrolige Breve til P. Vedel og Quaade ${ }^{3}$ udtrykte Grev Frijs sin Pessimisme. Han ansaa Eksplosionen for nær forestaaende, og det vilde da være et yderst kritisk Moment for dem, der enten „laa i Vejen eller paa Vejen for at de Vedkommende kunde komme i Haarene paa hinanden“. Vi kunde da, skrev Grev Frijs i sit kærnefulde knudrede Sprog, ,ikke alene risquere at blive overrendt, et os ikke i vor historiske Erfaring ubekjendt Phænomen, men paa Grund af de store Masser og Kræfter som ved denne Lejlighed ville komme i Bevægelse, risquerer man ligesaa let at quæles ved en alfor varm Omfavnelse, naar man skulde benyttes til en Slags débouché (Udgangssted), som man risquerer ved et Overfald i den noble Hensigt at uskadeliggjøres à la facon de Francfort og naturligviis dette $i$ en forhøiet Potents; $i$ begge Tilfælde kan den resterende Livskraft fuldstændig tilsættes" 4 .

1 Oubril til Gortchakow $\%$ Marts 1869 (Moskwa). Akter II, S. 219-28, 232-33. Akter II, S. 226-27.

akter II, S. 225. s Trykt i 
Der taltes mere og mere om truende Krigsforberedelser baade i Preussen og i Frankrig, og Grev Frijs indskærpede Quaade at skaffe Rede paa, hvorledes den militære Situation egentlig var. „Det gælder for os om at sælge vort Liv saa dyrt som muligt og tillige ikke at bortødsle løst Krudt, hverken i Talemaader eller i finantsiel Henseende."1 Det vilde efter hans Opfattelse for de smaa Stater allermest komme an paa at holde til Raade saavel med Mandskab som med Pengeudgift under den første Fase af den eventuelle Krig, hvor den allerstørste Hensynsløshed maatte befrygtes at finde Sted; naar den Periode var overstaaet, stod de bedre ved den endelige Opgørelse, hvis de ikke havde overanstrengt sig i Begyndelsen, men havde baade militære og finantsielle Kræfter i Behold; i saa Fald vilde deres relative Vægtfylde være større end i Begyndelsen af Krigen. Men yderligere mente Grev Frijs, at „efter vor nationale Ejendommelighed“ og „,ifølge den Landet iboende væsentlige finantsielle Kraft", var Chancerne snarest for at sejre ved Udholdenhed, mere „end ved en Begeistrings Overanstrængelse", fordi denne sidste aldrig i fuldt Maal kunde komme tilstede; "det er imod Nordboens, idetmindste Danskens Natur, og naar i enkelte Tilfælde Sligt kunstig er bleven skabt, er Folket paa en vis Maade kommet til at lee af sig selv, fordi det aldeles ikke har kunnet gjenkjende sig selv, men ligesom fundet sig besat af en fremmed svulstig, jeg havde nær sagt tydsk Aand“. Det forekom Grev Frijs, at det saa vel for en General som for en Statsmand maatte være paatrængende nødvendigt at skønne rigtigt om „de aandelige Fakulteter", han havde at disponere over $\mathrm{i}$ den ejendommelige Folkekarakter; det var kun ved at finde de sande Faktorer og at benytte det Stof, der forefandtes, at man kunde blive i Stand til at suge den størst mulige Nytte deraf. En Misregning i denne Henseende paa det aandelige Gebet maatte lige saa fuldt hævne sig, som naar Misregning fandt Sted med Hensyn til de legemlige Kræfter.

I Marts-April I 869 mente Grev Frijs, opfyldt af triste Tanker som han var, at hans Helbred ikke kunde holde til en fortsat Ministergerning under de nærværende Forhold; han befandt sig, skrev han den I8. Marts til Quaade, baade legemlig og aandelig i en Tilstand som „et Stykke mørbanket Kjød, hvor al Saft og Kraft er ude af" 2 . Det kunde vel se ud, som om Anstrengelserne ikke var store, „men dette aldrig at kunne skride fremad, men i det Allerhøjeste kun at kunne naae saa vidt, at man ikke gik noget Skridt tilbage", — dette var sløvende og berøvede En tilsidst den Ligevægt og Sindsro, som var absolut fornøden, naar man med Nytte skulde styre andre. Han haabede, at Sommeren vilde gaa rolig hen, saa han kunde slippe bort i August og September, som fri Mand

\footnotetext{
1 Akter II, S. 227. 2 Akter II, S. 228.
} 
drive Jagt paa Norges Fjælde, derefter omkring Aarsskiftet tage syd paa for at varme sig i Ægyptens Sol og overlade sine Efterfølgere Fornøjelsen i Folketing og Landsting. Han mente, at Størstedelen af hans Kolleger var udslidte, og det „evig at maatte gaa i Tøjet, snart mægle til den ene snart til den anden Side" virkede i høj Grad sløvende paa ham".

Ogsaa P. Vedel havde det Indtryk, at Ministeriet ikke kunde holde sammen eller holde sig ret længe; men da han sidst i April fortrolig fortalte Quaade, hvor pessimistisk Grev Frijs saa paa Stillingen og hvor usikkert det hele var, tilføjede han, at han næppe behøvede at sige, at han for sin Del gjorde alt, hvad han kunde for at holde Grev Frijs fra at gaa af. „Baade troer jeg, at han er den bedste Minister, vi for Tiden kunne faa, og han er for mig den behageligste Chef, der kan tænkes; vi arbejde godt sammen, og vi kjende nu hinanden." 2

Foreløbig holdt Ministeriet, men Rekreation maatte Grev Frijs dog have og den 21. April tog han nogle Ugers Ferie for sammen med sin Familie at bruge Badene i Marienbad. Den 12. Juni kom han tilbage til Danmark, og hans Rejse var blevet mærkelig ved, at den havde givet Anledning til et Møde mellem ham og Bismarck og dermed til den eneste personlige og mundtlige Drøftelse om Nordslesvigs Genforening med Danmark, der fandt Sted mellem Lederne af Danmarks og Tysklands Udenrigspolitik i hele Perioden fra 1864 til I920, da det nordslesvigske Spørgsmaal stod uløst hen ${ }^{3}$.

Til Marienbad rejste Grev Frijs over Wien og gjorde, for ikke at støde, den østrig-ungarske Rigskansler Grev Beust sin Opvartning 4. De talte om almindelige politiske Emner, men skønt Lejligheden bød sig, vilde Grev Frijs med Vilje ikke tale om Nordslesvig. Under de daværende spændte Forhold i Europa vilde en Drøftelse derom højst fremkalde en Opmærksomhed, der ingenlunde var ønske-

1 Akter II, S. 233 Akter, II, S. 234-35. ' 3 Endnu en Gang efter I869 drøftede ganske vist en dansk Udenrigsminister i Berlin Spørgsmaal vedr. Nordslesvig, nemlig da Grev RabenLevetzau, efter Kejser Wilhelm den II.s udtrykkelige Indbydelse ledsagede Kong Frederik VIII og hans Dronning, da disse den 19. og 20. November 1906 besøgte det tyske Hof. Men den Samtale, som Grev Raben den 2o. November førte om Forholdene i Nordslesvig, var ikke med Rigskansleren, Fyrst Bernhard v. Bülow, selv, men, efter Aftale, med dennes Stedfortræder, Statssekretæren v. Tschirschky und Bögendorff, og Genstand for Drøftelse var alene dels det almindelige Forhold mellem Danmark og Tyskland, dels den Konvention om Optanternes og Optantbørnenes Retsstilling, der just den Gang var under Forberedelse og, efter at den danske Regering havde raadfort sig med H. P. Hanssen, den I I. Januar 1907 blev afsluttet mellem den danske og preussiske Regering. Om en Endring af Nordslesvigs statslige Stilling kunde der, saaledes som Forholdene laa i de 30 Aar fra 1879 til 1918, ikke tales. Akter II, S. 236. 
lig, da man aldeles ikke kunde regne paa nogen virkelig Støtte hos Østrig. „Man vilde dog ikke gøre denne Sag til almindelig Krigsaarsag, uden efter en bestemtere Opfordring. Det kan vel nok siges, at man tit kan spøge og selv ønske at spøge saalænge med Ilden, at dennes Udbrud kan faae Udseende af et Accident uden at være det", men hvis man i Bedømmelsen heraf tog fejl, vilde vi alene komme til at betale Gildet ved at blive brugt som „Jouet" (Legetøj), skrev Grev Frijs til P. Vedel. Han paalagde den danske meget geskæftige Gesandt $i$ Wien, Kammerherre Falbe, at passe paa, at hans korte Ophold i Wien ikke blev brugt til „Røverartikler i en eller anden Retning, da det uden Hensyn til hans personlige Smag laae i Sagens Natur, at vi for Øjeblikket ikke kunde ønske alfor meget at henlede Opmærksomheden paa os "1. Det maatte fremfor alt være Danmark magtpaaliggende for hele Verden at tydeliggøre, at vi ikke satte vort Haab til at fiske i rørt Vande, men tværtimod til, at der under en fredelig Udvikling dog tilsidst vilde blive vist den lille mishandlede danske Stat Retfærdighed, saaledes at det derigennem blev almindelig erkendt, at den danske Stats Eksistens var nødvendig for hele det europæiske Statssamfund.

For at undgaa "Vidtløftighed og Mistydninger" 2 afslog Grev Frijs en Indbydelse til Middag hos Beust, men da han paa sin Udrejse havde hilst paa den østrigske Rigskansler, mente P. Vedel, at det, skønt Besøget i Wien havde været aldeles upolitisk, var passende, at den danske Konsejlspræsident lagde Vejen hjem over Berlin og gjorde Visit hos Bismarck, hvis det nordtyske Forbunds Kansler da var i Byen ${ }^{3}$.

I Marienbad var Grev Frijs glad ved at være udenfor alle pinlige Forretninger, og særlig glad ved ikke, som han havde frygtet, at træffe den slesvig-holstenske Overpræsident, sin gamle Bekendt Baron Carl von Scheel-Plessen, der „var den Personlighed, der personlig var ham meest imod" "4 ikke blot paa Grund af hans Holdning som slesvig-holstensk Fører før r 864, men ganske særlig, fordi han efter I864 var bleven Bismarcks haandgangne Mand og, efter Grev Frijs's og mange andre Danskes Opfattelse, havde en væsentlig Del af Skylden for at den preussiske Politik var saa ubehagelig mod Danmark og de danske Nordslesvigere.

Grev Frijs var overordentlig ked af at skulle afslutte sin fredelige Badekur med Besøg hos Bismarck. Han var forberedt paa at faa en mere eller mindre "schnöde" Afvisning, og det vilde han paa Grund af sin Stilling nødig udsætte sig for, selv om det personlig var ham ganske ligegyldigt. Efter nogen Brev-

1 Akter II, S. 236-37. Akter II, S. $23^{8} . \quad 3$ Korrespondancen herom er trykt Akter II, S. $23^{8-251 . ~} 4$ Akter II, S. 239 . 
veksling med Quaade og Vedel gik han dog naturligvis ind paa Vedels Henstilling. Om en Samtale med Bismarck kunde gavne, var han ude af Stand til at bedømme, men, skrev han til Vedel, „forsaavidt som det kunde bero paa hans Fremtræden, vilde han ret alvorlig og inderlig bede Vorherre at styrke ham til denne Gjerning og give ham Ligevægt og Disponibilitet i Sindet, hvilket just ikke var let umiddelbart efter en Badekur, under en eventuel Samtale, saa at denne idetmindste maatte bidrage til at skaffe nogen Agtelse selv hos en saa overmodig Mand som Grev Bismarck". Frijs havde hverken stor Tro til sine Overtalelsesevner eller Fortrøstning til, at der i Øjeblikket kunde udrettes noget for Danmarks Livssag, men da han ikke bestemt kunde benægte Muligheden, vilde han aldrig kunne forsvare for sig selv ikke at have gjort Forsøget. Just fordi det var ham i allerhøjeste Grad personlig ubehageligt og pinligt, vilde han bestandig gøre sig Bebrejdelser for at have taget mere Hensyn til egen Bekvemmelighed og Behagelighed end til, hvad der kunde gavne hans Fædreland, selv om Muligheden herfor var meget ringe ${ }^{1}$.

Han lagde da Hjemvejen over Berlin, og efter Henvendelse gennem Quaade modtoges han den Io. Juni Kl. I 2 beredvillig af Forbundskansleren; denne havde, da han paa Forhaand var meget stærkt optaget, bedt Grev Frijs spise hos sig, men da Frijs havde sagt, at det var umuligt, da han kom lige fra en Badekur, havde Bismarck trods sin knappe Tid ordnet Modtagelsen om Formiddagen ${ }^{2}$.

Det var ikke første Gang, de to Mænd mødtes, og til deres første Samvær var knyttet en pinlig Erindring ${ }^{3}$. I August 1857 havde Baron Blixen-Finecke og hans Svoger Landgrev Frederik af Hessen, Broder til den daværende Prinsesse Louise af Danmark, arrangeret en Jagtudflugt til Småland, hvor de havde ført Bismarck sammen med forskellige politisk betydende danske Godsejere, deriblandt Grev Frijs. Blixen havde haft en politisk Bagtanke ved at forestille sin personlige Bekendt, Forbundsgesandten fra Frankfurt, for de danske Herrer, men Grev Frijs var bleven højst forbitret over, at man, uden at der var sagt til i Forvejen, „havde slæbt politiske Personligheder op til et Møde, hvor man vilde fornøje sig med Jagd", saaledes at han ikke frit havde kunnet bestemme, om han under den Forudsætning vilde komme til Stede eller ej. Paa Grund heraf og ikke af nogen personlig Uvilje havde han derfor saa tydeligt som det vel var muligt uden just at være grov, vist Bismarck, at han „gav ham en god Dag. “ Dette var naturligvis ingen behagelig Baggrund for Mødet nu, men imidlertid, Besøget

${ }^{2}$ Akter II, S. $250-51$. ${ }^{2}$ Akter II, S. 252-53.

s Akter II, S. 252. Danske Magazin, 6. Rk. II, $3^{66 .}$ 
skulde jo vise, „at man var Herre over sine Følelser, ønskede at vise sædvanlig Høflighed, men hverken havde isinde at supplikere, ei heller at smigre Storheden"..1

Grev Frijs satte „sit mildeste Ansigt“" op og forsøgte, som han skrev til Vedel, at forstille sig saa godt som muligt; han havde dog under Samtalen den Følelse, at Bismarck ogsaa var en fuldkommen Mester heri. Forbundskansleren bestræbte sig ogsaa at give sig Udseende af "en frank og aaben Personlighed" 2 .

$\mathrm{Da}$ Cigaren var tændt, indledede Grev Frijs Konversationen med at sige, at han ikke havde villet rejse gennem Berlin uden at forny Bekendtskabet; det glædede ham at se Bismarck etc. etc., det var mærkeligt, at denne kunde holde saadan ud, skønt han havde Rigsdag og Parlament næsten stadig samlede. Derved kom Bismarck ind paa en længere Udvikling af, at det blev nødvendigt, at Kamrene højst samledes hvert andet Aar og af, at Toldparlamentet rimeligvis gik fuldstændig over Styr, idet Sydtyskere og Østrigere ikke i Længden kunde gaa sammen med Nordtyskerne. Grev Frijs bed Mærke i, at Bismarck i denne Forbindelse sagde, ,at man ikke var tjent med at faae Folk ind $i$ et Samfund eller Forbindelse, som ikke onskede at være der, thi det blev aldrig nogen Forøgelse af Kraft".

Hver Gang der blev en Pavse i Samtalen, blev Frijs ved at tale om „Sundhedshensyn og Bismarcks store Virksomhed", idet han var bestemt paa ikke selv at begynde paa at lukke sin Mund op om Nordslesvig, selv om han skulde blive siddende der til næste Dag. Dette maa Bismarck vel have forstaaet ${ }^{3}$; han tog i alt Fald selv fat paa Nordslesvig i Anledning af, at Samtalen kom ind paa det stadig brændende Luxembourg-Spørgsmaal, paa den sydtyske Presses Optræden overfor Nordtyskland og paa Angreb paa ham personlig, som han beklagede sig over. I dette Tilfælde som ofte, naar Bismarck overhovedet drøftede det nordslesvigske Spørgsmaal, tog han sit Udgangspunkt i „en Fremstilling af den politiske Stilling og sin egen næsten umulige Stilling under Forhandlingerne $i$ Nikolsburg, da Kong Wilhelm var bleven hidset og pustet Ild til af Generalerne og hvor han aldeles bestemt havde maattet indgive sin Demission". Den eneste, der havde holdt med ham, var General Moltke, men Kongen havde slet ikke villet indlade sig paa at afgøre Sagen med, at Haderslev Amt tilbagegaves til Danmark; det havde Bismarck ønsket, og dermed vilde Franskmændene have været fornøjede, thi de saa ikke saa meget paa Gebetets Størrelse; det havde snarest været for en Forms Skyld (c'était plutôt pour la forme). Bismarck var

${ }^{1}$ Akter II, S. 251-52. $\quad{ }^{2}$ Akter II, S. 253. $\quad{ }^{8} \mathrm{Sml}$. Depeche fra Mohrenheim til Westmann 8/20 August I869 (Moskwa). 
overbevist om, at det havde været det ønskeligste, om Sagen den Gang var bleven endelig afgjort; det havde været langt lettere, men han havde kun faaet Moltke til at gaa ind paa sin Opfattelse, at Preussen var bedre tjent med at faa Sagerne endelig ordnede og $i$ det hele taget paa en Maade, der ikke altfor stærkt saarede andres Interesser. Mere end Haderslev Amt havde han ikke tænkt at genafstaa til Danmark; men heri havde han altsaa ikke faaet Medhold; langt mindre var der derfor Tale om, at han eller nogen vilde gaa ind paa, hvad man fra dansk Side ønskede. Siden 1866 havde Forholdene ingenlunde bedret sig til Fremme af de danske Ønsker; om ogsaa han kunde ønske en Afgørelse, saa stod han nu saa at sige alene. Kong Wilhelm vilde ikke miste sin tyske Popularitet, og saa snart Sagen omtaltes i Bladene, mødte der Adresser og Petitioner fra Haderslev om den Ulykke, der vilde vederfares de derværende Tyskere. Heraf benyttede Kongen sig, og hos Kamrene fandt Bismarck ikke nogen Støtte, endnu mindre i Pressen, thi da vilde først for Alvor alle welfiske, hessiske og beust'ske Blade blæse Alarm.

I denne Forbindelse gav Bismarck dog „en fin Antydning af, at der muligvis under de forestaaende Begivenheder vilde findes en gunstig Tid“.

Til denne Antydning bemærkede Grev Frijs, at han var overbevist om, at det maatte være $i$ fælles, og $i$ alt Fald i dansk Interesse, at Spørgsmaalet kunde afgøres alene af de to Parter, som det vedkom, idet en Afgørelse vundet ad denne Vej vilde skabe et permanent Venskabsforhold. Yderligere bemærkede han, at den danske Konge jo ikke lagde Vægt paa, om der vandtes mere eller mindre Land, men det kom an paa, „at den nationale Individualitet, som han repræsenterede, vandt den berettigede Anerkendelse og Agtelse, hvilket under de nuværende Forhold ikke fandt Sted“. Hele Danmark ønskede, som Kong Christian gentagne Gange havde udtalt, $i$ højeste Grad at komme paa en god Fod med Tyskland og Preussen, men dels hørte hertil to Viljer, der samstemmede, dels var det en nødvendig Forudsætning, at den nationale Individualitet respekteredes; uden dette kunde den gensidige Bestræbelse fra Regeringernes Side ikke faa nogen sand Grund at bygge paa. Bismarck omtalte Tyskernes Stilling i de Dele, der eventuelt skulde tilbagegives Danmark; man kunde dog ikke tvinge dem til at flytte, men hertil bemærkede Grev Frijs, at det var alle Dage en Besværlighed, hvoraf Danmark kom til at bære Byrden.

Da Samtalen, der naturligvis var bleven ført i den største Høflighed, havde varet en tre Kvarterstid, kom Grevinde Bismarck og kigede ind ad Døren. Grev Frijs troede, at det enten maatte være et aftalt Tegn eller viste, at Bismarck virkelig skulde af Sted; han overbeviste sig senere om, at den sidste 
Formodning var rigtig; han anbefalede sig derfor efter at have gjort Bekendtskab med Grevinden.

Da han kom ud paa Gaden og hastigt begav sig til sit Hotel for straks efter at rejse til Hamburg, følte han sig meget medtaget; efter Badekuren virkede enhver fortsat aandelig Beskæftigelse stærkt paa ham og jog ham Blodet til Hovedet. $\mathrm{Nu}$ saa han ud som en kogt Krebs, men han havde under hele Samtalen gjort den Iagttagelse, at ogsaa Bismarck var meget medtaget, omend vel ikke af Samtalen, saa $i$ det hele taget. Frijs fandt ikke, at Bismarck havde vundet i Udseende ved det anstrengende Arbejde og den Indflydelse, han havde haft paa Verdens Gang i de Aar, der var gaaet siden de første Gang havde set hinanden. De Spor, Begivenhederne havde efterladt paa hans Fysiognomi, havde hverken virket forskønnende eller forædlende; Bismarck gjorde et nervøst og noget opdunstet Indtryk, saa angrebet ud, oppustet i Ansigtet. Grev Frijs troede ikke, at Bismarck længe kunde holde dette Liv ud, hans Legeme vilde ikke kunne bære den aandelige Modgang, som han ligesom enhver var udsat for. Naar Bismarck i Samtalens Løb ufrivillig og som instinktmæssigt havde ytret, at det havde været bedre, om man tidligere havde økonomiseret med Tid og Kræfter for nu at kunne være fuldstændig Herre over dem, forekom det Frijs, „at det lød som et Hjertesuk af en ærgerrig Sjæl, der saa, at det gik nedad Bakke“. Dette Grev Frijs' Indtryk af Bismarcks legemlige Svaghedstilstand og aandelige Medtagethed svarede til andres i samme Tid, men han som de fleste undervurderede Bismarcks Kræfter; den væsentligste og mest oprivende Del af hans Livsgerning laa i Fremtiden.

De to Herrer skiltes med Haab om Gensyn, men Frijs' stiltiende Ønske var rigtignok, at et saadant „maatte blive under noget gunstigere Vilkaar for ham eller den danske Repræsentant og ikke under de nuværende Forhold, hvor den preussiske Premier og det hele Væsen staaer med det rasende Hovmod og Overmod lige overfor det øvrige Europa, navnlig lige overfor Danmark“. Skønt Samtalen var forløbet uden mindste ubehagelige Incident, havde den været Frijs meget pinlig og var, som han mente, en meget slet Efterkur. Alligevel var han overbevist om, at han havde handlet rigtigt $i$ at opsøge Bismarck, men „noget behageligt eller lovende Indtryk" havde Samtalen ikke gjort paa ham. Han mente imidlertid ,at have fastholdt det gamle eller hidtilværende danske Standpunkt" og havde ikke følt sig fristet til i noget Punkt at fravige dette.

Den 10. Juni om Aftenen naaede Grev Frijs Hamburg. Den følgende Dag skrev han til Kong Christian om Besøget og gav umiddelbart efter P. Vedel en længere Beretning, idet han, medens Samtalen endnu var levende i hans Erin- 
dring, vilde have nedskrevet sit Indtryk af den ${ }^{1}$. Da han kom hjem, fortalte han naturligvis baade Kongen og Vedel og enkelte andre flere Enkeltheder. Det skete dog med en vis Forsigtighed, som han'straks havde angivet overfor Vedel, da han i sin første Beretning bad denne beholde de fleste Bemærkninger om det Indtryk, Bismarck havde gjort paa ham, hos sig selv. Samtalen havde gjort ham klart, at Bismarcks Ømfindtlighed overfor Kritik saavel i Blade som af Personer vedrørende ,ikke alene hans Færd, men ogsaa selve det ydre Habitus", var bleven ganske overordentlig forøget i den senere Tid; det var ham derfor meget magtpaaliggende, at hans kritiske Bemærkninger ikke kom Bismarck for Øre.

Besøget kunde og skulde selvfølgelig ikke være nogen Hemmelighed, men det ser ikke ud til, at det vakte større Opmærksomhed, eller at man tillagde det væsentlig Betydning. Straks efter sin Tilbagekomst til København efter Besøg paa sine Godser i Jylland fandt Grev Frijs sig foranlediget til at opsøge den franske Gesandt, Dotézac, og udførlig fortælle om Samtalerne i Wien og Berlin ${ }^{2}$; nogle Uger senere gav han den russiske Gesandt, Baron Mohrenheim, et tilsvarende Referat ${ }^{3}$. Ogsaa den belgiske Minister van Loo hørte om Sagen ${ }^{4}$ og ligeledes den tyske Gesandt, Hr. v. Heydebrand und der Lasa ${ }^{5}$. Hverken i Heydebrands officielle Indberetninger eller $i$ hans Regerings Skrivelse til ham er Samtalen omtalt; den belgiske Gesandt nævnede kort Indholdet, men baade Dotézac og Mohrenheim gav paa Grundlag af Grev Frijs' Meddelelser udførligere Besked. I alt væsentligt svarede disse Referater til Grev Frijs' egne Beretninger til Kong Christian og Vedel; Mohrenheim billigede udtrykkelig den stærke Tilbageholdenhed, som den danske Udenrigsminister havde vist baade overfor Beust og overfor Bismarck.

Grev Frijs var interesseret $i$ at erfare noget om, hvilket Indtryk han paa sin Side havde haft af Samtalen; han ventede "despecteerlige Ytringer", idet det stod ham klart, at Bismarck ,i sit Overmod oversaa alt, hvad der ikke havde tilstrækkeligt Antal af Bajonetter"o. Det var dog mere af politisk end af personlig Interesse, at Grev Frijs ønskede at vide, hvad Bismarck havde sagt; han ventede hverken efter sit tidligere Kendskab til Bismarck ej heller efter det sidste Møde at finde nogen gunstig Bedømmelse af sin Person. Ønsket blev, saa vidt det kan ses, ikke tilfredsstillet. Quaade kunde intet indberette, og Samtalen

1 Brevet til Kongen findes i Kongehusets Arkiv i R. A; Brevet til Vedel er trykt Akter II, S. 25I-257. 2 Origine sdiplomatiques de la guerre de $1870-7 \mathrm{I}$ T. XXV, S. $3^{8} \mathrm{f} .{ }^{3}$ Mohrenheim til Gehejmeraad Westmann ${ }^{8} / 20$ 1869 (Moskwa). ' Van Loo til van der Stickelen $2 / 7$ 1869 (Bruxelles). 5 Akter II, S. 258. Akter II, S. $25^{8}$. 
findes, efter hvad der foreligger oplyst ${ }^{1}$, hverken omtalt skriftlig i nogen Optegnelse fra Bismarck eller mundtlig til nogen af de mange, der nedskrev Ytringer af ham. Han har formentlig ikke tillagt den nogen Betydning. Hans Udtalelser har Frijs utvivlsomt $i$ alt væsentligt gengivet korrekt; de svarer nøje til, hvad vi ellers ved om hans Standpunkt til det nordslesvigske Spørgsmaal paa hint Tidspunkt. Dette Standpunkt var uden Velvilje i Gærning.

1 Haehnsen, Ursprung und Geschichte des Artikels V des Prager Friedens II, S. 257. 